\title{
The Relationships of Happiness and Job Satisfaction to Job Performance of Public Secondary School Teachers in Selected Schools in the Division of Cavite
}

\author{
Jackie D. Urrutia, Paolo Christopher R. Borja, John Carlo D. Castillo, Raymond A. Magana
}

\begin{abstract}
The study analyzed the relationships of approaches to happiness and job satisfaction to job performance. This research endeavors to educate and inspire public academic institutions to focus on the happiness and job satisfaction of its teaching staff and see if it will bring out high job performance rate. A sample of two hundred and eighty-three (283) public secondary school teachers was taken from selected schools in the division of Cavite calculated based on Cochran's formula and using simple random sampling technique. The researchers used descriptive statistics such as frequency distribution and weighted mean to present the data. Pearson Product Moment Correlation Coefficient $r$ and multiple linear regression (MLR) model were used to determine the association and test statistical significance between all studied parameters. Data analysis was done using Statistical Package for the Social Sciences (SPSS). The findings of this study indicated that the extent of correlation between the approaches to happiness and job performance and between the job satisfaction and job performance are both significant. When these variables are linked with job performance, the outcome revealed that higher degrees of happiness - in terms of pleasant life, good life, and meaningful life-and job satisfaction lead to very satisfactory job performance.
\end{abstract}

Keywords: Happiness, job satisfaction, job performance, Multiple Linear Regression, Division of Cavite

\section{INTRODUCTION}

In contemporary times behavior has come to play an important part in many aspects of human activities. In an article by CNN Philippines (2017) [1], Jobstreet.com presented the Annual Happiness Index Report indicating that Filipinos are less happy in the workplace. Filipinos averaged 4.97 this year - a slight drop from 5.25 score last 2016. Job satisfaction of every employee will lead to a great job performance. Researchers Amabile\& Kramer (2011) [2] and Harris, Hinds, Manansigh, Rubino, \&Morote (2016)[3] proposed high employee morale and happiness as key to increased workplace productivity. As mentioned, happiness and job satisfaction of employees go together in achieving high performance rate of an organization. It is an accepted view in management circles that a happy worker is a productive worker. Further, Harris, et.al (2016) accentuated that employees who are happy to serve the institution they are with are also happy to serve their customers. Thus, this may lead to excellence and distinction.

Happiness, job satisfaction, and job performance are reported in nearly all studies as positively correlated with one another. For this reason, this study aims to examine this established tenet among professionals in the education sector, specifically the public secondary school teachers in selected schools in the Division of Cavite. Quantitative researches with regard to the said relationships are still lacking despite the promising aid this may bring to public schools here in the country. Further, this research endeavors to empower public institutions to focus on the "happiness" of its faculty members and see if it will bring out high job performance rate.

\section{RESEARCH PARADIGM}

As shown in Figure 1 below, the research paradigm presents the independent variables which include the three types of happiness. According to Seligman (2003), these are as follows: pleasant life or positive emotions, good life or engagement, and meaningful life [4]. Another set of independent variables are motivators and hygiene factors. Both happiness and job satisfaction are linked together because of their fundamental relationship. The dependent variable in this study is job performance of public secondary school teachers which was represented by the performance rating culled from Individual Performance Commitment and Review Form (IPCRF).
Revised Version Manuscript Received on 10, September 2019.

Jackie D. Urrutia, Professor,College of Education-Graduate School, Polytechnic University of the Philippines, Sta. Mesa, Manila, Philippines.(Email:jackieurrutia20@gmail.com,jdurrutia@pup.edu.ph)

Paolo Christopher R. Borja, Teacher II, Talon National High School, Cavite, Philippines.(Email: borjapaolochristopher@gmail.com)

John Carlo D. Castillo, Teacher I, San Joaquin-Kalawaan High School, Pasig City, Philippines. (Email: johncarlo.castillo76@gmail.com)

Raymond A. Magana, Project Evaluation Officer, City Government of San Jose del Monte, Bulacan, Philippines. (Email: mondimagana@gmail.com)

\section{Published By:}




\section{Happiness \\ - Pleasant life, Good life, Meaningful life \\ Job Satisfaction \\ - Motivators (Intrinsic Factors) -Achievement, Advancement, \\ Work itself, Recognition, Growth \\ - Hygiene (Extrinsic Factors) -Company policy, Relationship with Peers, Work Security, Relationship with Supervisor, Salary, Working Conditions \\ INDEPENDENT VARIABLES}

\section{Figure 1. Research Paradigm}

\section{A. Objective of the Study}

The general purpose of the study was to determine on how approaches to happiness and job satisfaction correlated to job performance of teacher-respondents. Specifically, the study aimed to identify the demographic profile of the public secondary school teachers; determine their response in terms of approaches to happiness, job satisfaction and job performance; identify the intrinsic and extrinsic factors that can affect the job performance.

\section{B. Scope and Limitation}

This study was conducted to the public secondary school teachers in selected schools in the division of Cavite during academic year 2017-2018.

The major limitations of this study were resource constraint including time, funding, and full access to information. Obtaining information from the teacher-respondents was, in some way, incredibly difficult due to the busy nature of their work schedule. Researcher, gathered data by the used of survey questionnaire. This was prepared in accordance with the statement of the problem. The researchers used job satisfaction survey and degree of happiness standardized questionnaires. A-three part survey questionnaire was used as researched instrument. Part I dealt on the profile of the respondents. Part II focused on Authentic Happiness as measured in the standardized instrument developed by Christopher Peterson called approaches to happiness. The instrument was used with the permission from Dustin Troy R. Joson, MBE by sending him an email. Lastly, Part III is all about measuring the level of job satisfaction of public high school teachers as that presented in the two Two-Factory Theory of Dr. Frederick Herzberg using the job satisfaction index. Moreover, the study considered facets of job satisfaction such as compensation or salary, promotion, working conditions, relationship with co-workers, relationship with supervisors/managers, nature of work, management recognition, safety at the workplace, and training and development. However, there may be other factors, specific factors to be précised that may affect job satisfaction level which the study did not explicitly explore.

\section{REVIEW AND RELATED LITERATURE}

Much has been said and written about job performance. Many studies have sought to investigate and identify the factors that influence employee performance in an organization. Apparently, most studies report that positive emotions improve performance and influence the capacity of workers for innovation (Proto, 2016) [5]. Happiness, for one, has become a building block of positive job performance in the workplace. Happiness is defined as a state of well-being, mental or emotional, involving positive or pleasant emotions such as contentment and satisfaction. One model that is fundamental for understanding happiness is the Authentic Happiness of Dr. Martin E.P. Seligman. Happiness could be analyzed according to three manageable and measurable elements: positive emotion, engagement, and meaning (Seligman, 2002). Researchers (Scorsolini-Comin, Fontaine, Koller, \& dos Santos, 2013 [6]; Buragohain\&Hazarika, 2015 [7]) have elaborated Seligman's postulation and have long recognized these elements appear to be vital in a threefold path of happiness - pleasant life, good life, and meaningful life. Interestingly, empirical evidence from researches showed that people who pursue all three approaches to happiness are said to be living a "full life" (Peterson, Park, \& Seligman, 2005 [8]; Brdar, 2009 [9]). Hence, people who live a "full life" are considered the happiest, have good self-control and know which goals to choose (Anić\&Tončić, 2013)[10].

As most people spend a major part of their adult life at work, it is natural that their well-being has a direct impact on work life. Asiyabi\&Mirabi (2012) [11] advocated that there is a close interrelation between an individual's work and life. Happiness in the workplace is an umbrella concept that includes a large number of happiness-related constructs ranging from short-lived events to chronic conditions in the task, job, and organization. Workplace happiness is also influenced by stable attributes of individuals such as personality, as well as the fit between what the job or organization provides, and the individual's expectations, needs, and preferences (Fisher, 2010) [12]. Further, researchers Wesarat, Sharif, \& Abdul Majid (2014) [13] cited key factors which influence happiness at the workplace such as employment status, income, friendship, and work activities. What these constructs have in common is that all are referred to as pleasant judgments or pleasant experiences at work (Bakker \&Oerlemans, 2011) [14]. In the case of professionals in the education sector, the territory of the schools, type of management of the schools, leadership style of the administration, and nature of appointment of the teachers significantly affect the well-being of secondary school teachers, because it directly motivates or de-motivates them (Buragohain\&Hazarika, 2015). In conclusion, all the studies clearly suggest that happiness at work depends on what is happening at present with the amalgamation of employee's philosophy about work.

Another emerging topic in management and organization is job satisfaction. The term "job satisfaction" was brought to public attention by Robert Hoppock (1935) [15]. He defined 
job satisfaction as, "any combination of psychological, physiological, and environmental circumstances that cause a person truthfully to say I am satisfied with my job." Subsequently, job satisfaction has been described and contextualized in so many ways over the years. In describing job satisfaction, the reference is often made to Edwin A. Locke's (1969) [16] definition as a "pleasurable or positive emotional state resulting from the appraisal of one's job or job experiences". More recent researchers have supplied explanation to job satisfaction. According to Statt (2004) [17], it is a feeling of being contented by the rewards of the job, particularly through intrinsic motivation. Armstrong (2006) [18] stated that positive feelings and attitude towards work indicate job satisfaction. Negative thoughts or feelings will lead to job dissatisfaction of every employee. Feeling of excitement going to work every day is a sign that a person is satisfied to the job. Robbins \& Judge (2007) [19] acknowledged it as a positive feeling about one's job resulting from an evaluation of its characteristics.

The relationship between satisfaction and performance in the workplace has been studied extensively throughout the history of organizational/ industrial psychology (Cook, 2008) [20]. Dr. Frederick Herzberg's Two-Factor Theory is one content theory that focuses attention on the work itself as a principal source of job satisfaction. His findings revealed that certain characteristics of a job are consistently related to job satisfaction, while different factors are associated with job dissatisfaction. In support to the works of Herzberg, authors Alegre, Gomez, Lopez, \&Mapa (1999) [21] cited that there are certain factors in the workplace that cause job satisfaction, while a separate set of factors cause job dissatisfaction. Job satisfaction of employees, particularly among teachers, results to a better performance because they are motivated in what they do. The positive feelings and attitude towards work lead teachers to put more effort in every single task they handle (Alemi, 2014) [22]. Satisfied teacher can contribute immensely to the well-being of his/her students and peers as well as to the effectiveness of program of education, and finally helping the country to achieve the vision. A dissatisfied teacher, though, can become irritable and may display tensions which can have negative influence on the learning process, and it consequently affects their academic growth (Thakur, 2014 [23]; Abdullah, Uli, \&Salahudin, 2007 [24]). Most studies revealed that teachers salary, work condition/infrastructure, work itself, job security, and provision for promotion. De Kok (2013) [25] stated that salary, working conditions and hours, and all that influence how people view their work are the factors that make the employee satisfied with their job. Satisfaction of an employee will significantly affect their job performance. Factors such as cooperation, mutual respect, suitable salary, and working environment lead to job satisfaction. Subhashini (2017) [26] affirmed that the more job experiences a person acquired, the higher the degree of job satisfaction compared with less job experience. happy or lonely with his job. In connection to this, a study by Üredi (2017) [27] found out that the level of job satisfaction of teachers toward the teaching profession affects their teaching performance. He concluded that the "psychological were seemingly satisfied and dissatisfied with the aspects of

Job satisfaction often suggests that an employee is either

beliefs" of the teachers affect their students in so many ways since they spend most of their life at school. Teachers with high job satisfaction level have great classroom management skills and good sense of self-improvement for the betterment of their students. In addition, teachers who find satisfaction with their job continuously seek self-improvement through attending seminars and accessing short courses to continue their professional development, thus impacting their performance in teaching. In another research, it was revealed that teacher-respondents were satisfied with their performance in related skills, abilities, initiatives, and productivity, exceeding requirements in many of the area of work performance (Usop, Askandar, Langguyuan-Kadtong\&Onotan-Usop, 2013) [28].

At its very core, work is essential to human. Having a job is a way for a person of getting involved in something much bigger than him. The role of job is not only meant as a source of income so that one can buy and satisfy his or her basic necessities, but also a way that many people validate their capabilities and self-worth (Riley, 2016) [29].

\section{MATERIALS AND METHOD}

\section{A. Research Method}

The methodology used for this study relied mostly on descriptive survey. Ali (1996)[30], in his Fundamentals of Research in Education, defined descriptive survey as a research methodology in which a group of people or items are studied by collecting and analyzing data from only a few people or item considered to be representative of the entire group. This design is considered to be fitting because the study involves data collection in a natural setting. The study used descriptive design because it focused on the relationships of approaches to happiness and job satisfaction to job performance of public school teachers. Further, descriptive research is not only concerned with fact gathering, but also with identifying and predicting relationships between variables. A descriptive research determines and reports the way things are, since it has no control over what was and what is. It can only measure what already exists.

\section{B. Sampling Technique}

The population size is 1,070 public secondary school teachers. Researchers had a sample of two hundred and eighty-three (283) public secondary school teachers was taken from selected schools in the division of Cavite calculated based on Cochran's formula and using simple random sampling technique. Below is the formula for Cochran that was used to determine the total sample size.

$$
n=\frac{n_{o}}{1+\frac{\left(n_{o}-1\right)}{N}}
$$

\section{Research Instrumentation}

Researcher, gathered data using standardized survey questionnaire. This was prepared in accordance with the statement of the problem. A three-part survey questionnaire 
was used as research instrument. Part I delved on the profile of the respondents. Part II focused on Authentic Happiness as measured in the standardized instrument developed by Christopher Peterson called approaches to happiness. The instrument was used with the permission from Dr. Martin E.P. Seligman (seligman@ @sych.upenn.edu) by sending him an electronic mail thru the kind assistance of Dr. Margaret Kern (margaret.kern@email.ucr.edu). Lastly, Part III examined the level of job satisfaction of public high school teachers as that presented in the Two-Factory Theory of Dr. Frederick Herzberg using the Job Satisfaction Index. Moreover, the study considered facets of job satisfaction such as compensation or salary, promotion, working conditions, relationship with co-workers, relationship with supervisors/managers, nature of work, management recognition, safety at the workplace, and training and development.

\section{Data Collection Method}

The questionnaires were administered directly to the chosen sample for the study. Two hundred and eighty-three (283) copies of the questionnaire given out were successfully completed and retrieved. The achievability of retrieving back all the questionnaires was as a result of the researchers' perseverance and determination despite the busy nature of work schedule of teacher-respondents and the schools' proximity constraints.

\section{E. Statistical Tools}

The questionnaires were administered directly to the chosen sample for the study. Two hundred and eighty-three (283) copies of the questionnaire given out were successfully completed and retrieved. The achievability of retrieving back all the questionnaires was as a result of the researchers' perseverance and determination despite the busy nature of work schedule of teacher-respondents and the schools' proximity constraints.

Upon the successful retrieval of the questionnaire, data were organized and tallied systematically. Descriptive statistics mainly frequency count and percentages, mean, correlation, and multiple linear regression analysis were used by employing SPSS computer software in the presentation, analysis and interpretation of the findings.

The statistical formulas used were the following:

\section{Frequency Count and Percentage}

To compare the respondents response derived from the demographic profile, this statistical tool was used. It is calculated with the use of the following formula:

$$
p=\frac{f}{n} \times 100
$$

Where: $\mathrm{P}$ is the percentage

$\mathrm{f}$ is the frequency

$\mathrm{n}$ is the number of cases

\section{Mean}

The mean or average gave a very good idea about the central tendency of the data collected. The computation of the mean was used in identifying the extent on the positive discipline approaches used by the teachers.

$$
\mu=\frac{\sum f}{n}
$$

The formula for obtaining the mean is:

\author{
Where: $\mathrm{M}$ is the mean \\ | is the summation \\ $\mathrm{f}$ is the frequency| \\ $\mathrm{n}$ is the number of cases
}

\section{Pearson Product Moment Coefficient}

To quantify the association between two variables, correlation analysis was used. This was used to correlate the profile of the respondents to positive discipline approaches used by the teachers. The formula for computing the correlation coefficient is.

$$
r=\frac{n\left(\sum x y\right)-\left(\sum x\right)\left(\sum y\right)}{\sqrt{\left[n \sum x^{2}-\left(\sum x\right)^{2}\right]\left[n \sum y^{2}-\left(\sum y\right)^{2}\right]}}
$$

where:

$$
\begin{aligned}
& r=\text { Pearson } r \\
& N=\text { the total number of respondents } \\
& \mathrm{x}=\text { the first variable } \\
& \mathrm{y}=\text { the second variable }
\end{aligned}
$$

The obtained data was interpreted based on the Rules of Thumb Size of Correlation Coefficient presented by Hinkle et al (2003) in the book Applied Statistics for the Behavioral Sciences $\left(5^{\text {th }}\right.$ Edition) [31].

\section{Multiple Linear Regression Analysis.}

To determine the intrinsic and extrinsic factors that affects the job performance multiple linear regression analysis was used. This was used to identify the factors that is significant to the job performance of the teacher-respondents. Formally, the model for multiple linear regression[32], given $n$ observations, is:

$$
y_{i}=b_{0}+b_{1} X+b_{2} X+\ldots b_{n} X
$$


Table 1

Table of Specification for Approaches to Happiness and Job Satisfaction Index

\begin{tabular}{ll}
\hline INSTRUMENT & $\begin{array}{l}\text { ITEM } \\
\text { PLACEMENT }\end{array}$ \\
\hline Approaches to Happiness & \\
\hline $\begin{array}{l}\text { Pleasant Life (Pleasures) } \\
\text { Key thought (Happiness is seen } \\
\text { through our expressions) }\end{array}$ & $18,19,13,15,16$, \\
\hline $\begin{array}{l}\text { Good Life (Flow) Key thought } \\
\text { (Happiness is not the end but the }\end{array}$ & $1,4,6,7,9,10$, \\
means to the end) & \\
\hline $\begin{array}{l}\text { Meaningful Life (Meaning) Key } \\
\text { thought (Happiness is living life that }\end{array}$ & $2,12,14,17,20$ \\
is larger than one's own) & \\
\hline Job Satisfaction Index & \\
\hline Motivators (Intrinsic Factors) & $1,2,3$ \\
\hline Achievement & $4,5,33$ \\
\hline Advancement & $6,7,8$ \\
\hline Work itself & $9,10,11,12$ \\
\hline Recognition & $13,14,15,32$ \\
\hline Growth & \\
\hline Hygiene Factors (Extrinsic Factors) & $16,17,18$ \\
\hline Company Policy & $19,20,21$ \\
\hline Relationship with Peers & $22,23,24$ \\
\hline Work security & $25,26,27$ \\
\hline Relationship with Supervisor & 28,29 \\
\hline Salary & 30,31 \\
\hline Working conditions & \\
\hline & \\
\hline
\end{tabular}

Table 2

Arbitrary Scales for Approaches to Happiness, Job Satisfaction Index and IPCRF Verbal Interpretation

\begin{tabular}{llll}
\multirow{2}{*}{$\begin{array}{l}\text { Scale } \\
\text { Numerical } \\
\text { Rating }\end{array}$} & $\begin{array}{l}\text { Verbal Interpretation } \\
\text { to }\end{array}$ & $\begin{array}{l}\text { Jappiness } \\
\text { Satisfaction } \\
\text { Index }\end{array}$ & \\
\hline 4.51 - 5.00 & $\begin{array}{l}\text { Very Much } \\
\text { Like Me }\end{array}$ & $\begin{array}{l}\text { Strongly } \\
\text { Agree }\end{array}$ & Outstanding \\
\hline $\mathbf{3 . 5 1 - 4 . 5 0}$ & $\begin{array}{l}\text { Mostly } \\
\text { Like Me }\end{array}$ & Agree & $\begin{array}{l}\text { Very } \\
\text { Satisfactory }\end{array}$ \\
\hline $\mathbf{2 . 5 1}-\mathbf{3 . 5 0}$ & $\begin{array}{l}\text { Somewhat } \\
\text { Like Me }\end{array}$ & Neutral & Satisfactory \\
& $\begin{array}{l}\text { A Little } \\
\text { 1.51 - 2.50 }\end{array}$ & Disagree & Unsatisfactory \\
& Like Me & & \\
\hline
\end{tabular}

The table of specification in table 1 and 2 was formulated from the study by Peterson, Christopher; Park, Nansook; and Seligman, Martin E.P. (2005) entitled, "Orientations to Happiness and Life Satisfaction: The Full Life Versus the Empty Life" with written permission to use instrument sent to Dr. Martin Seligman via electronic mail. It also shows the same is true for the table of specification of the Job Satisfaction Index. It was formulated from the study of Teck-Hong, Tan and Waheed, Amna (2011) entitled, "Herzberg's Motivation-Hygiene Theory and Job Satisfaction in the Malaysian Retail Sector: The Mediating Effect of Love of Money" [33].

In table 2, for the dependent variable, job performance, the researchers made us of the standardized tool called Arbitrary Scale for Individual Performance Commitment and Review Form (IPCRF) used by the Department of Education to evaluate the individual performance of each teacher in the Philippines. The said tool is used by the teacher to carefully evaluate his/her own performance in terms of (1) Teaching and Learning Process; (2) Student Outcomes; (3) Community Involvement; (4) Professional Growth and Development; and (5) Plus factor. After which the school head will talk with the teacher about his/her self-rating and try to collaborate on a grade that is in consonance with eh school head's observation. Please see Appendix for the content of the Individual Performance Commitment and Review Form (IPCRF).

\section{RESULTS AND DISCUSSION}

Data from the demographic part of the survey (Table 3) revealed that the majority age of the teacher respondents is between $31-40$ years old with $37.46 \%$. It also revealed that most of the teachers has earned units in their Masteral Degree with $59.7 \%$. Furthermore, the sample consisted of teachers with teaching experience from being a newly hired teacher 36 years and above. $37 \%$ of the total respondents had a work experience of $2-5$ years. Additionally, there were $37.1 \%$ of the teacher respondents has a position of Teacher 2 and most of them are teaching Filipino subject with $20.8 \%$. Lastly, majority of the teacher respondents are receiving monthly salary ranging from Php21,000-25.999 with 50.5\% 
The Relationships of Happiness and Job Satisfaction to Job Performance of Public Secondary School Teachers in Selected Schools in the Division of Cavite

Table 3

Frequency and Percentage Distribution of Demographic Profile of the Teacher Respondents

\begin{tabular}{|c|c|c|}
\hline PROFILE & f & $(\%)$ \\
\hline \multicolumn{3}{|l|}{ AGE } \\
\hline 21-30 years old & 84 & $29.68 \%$ \\
\hline $31-40$ years old & 106 & $37.46 \%$ \\
\hline 41-50 years old & 64 & $22.61 \%$ \\
\hline 51 years old and above & 29 & $10.25 \%$ \\
\hline \multicolumn{3}{|c|}{ HIGHEST EDUCATIONAL ATTAINMENT } \\
\hline Master's Degree Holder & 34 & $12 \%$ \\
\hline Bachelor's Degree Holder & 62 & $21.9 \%$ \\
\hline With Ed.D/Ph.D Units & 18 & $6.4 \%$ \\
\hline With MA Units & 169 & $59.7 \%$ \\
\hline \multicolumn{3}{|l|}{ TENURE } \\
\hline Newly hired - 1 year & 15 & $5.3 \%$ \\
\hline $2-5$ years & 105 & $37 \%$ \\
\hline $6-10$ years & 81 & $28.5 \%$ \\
\hline $11-15$ years & 19 & $6.7 \%$ \\
\hline $16-20$ years & 19 & $6.7 \%$ \\
\hline $21-25$ years & 22 & $7.7 \%$ \\
\hline $26-30$ years & 8 & $2.8 \%$ \\
\hline $31-35$ years & 8 & $2.8 \%$ \\
\hline 36 years and above & 6 & $2.1 \%$ \\
\hline \multicolumn{3}{|l|}{ POSITION } \\
\hline Teacher 1 & 15 & $5.3 \%$ \\
\hline Teacher 2 & 105 & $37.1 \%$ \\
\hline Teacher 3 & 81 & $28.6 \%$ \\
\hline Master Teacher 1 & 19 & $6.7 \%$ \\
\hline Master Teacher 2 & 19 & $6.7 \%$ \\
\hline Master Teacher 3 & 22 & $7.8 \%$ \\
\hline Head Teacher 1 & 8 & $2.8 \%$ \\
\hline Head Teacher 2 & 8 & $2.8 \%$ \\
\hline Head Teacher 3 & 6 & $2.1 \%$ \\
\hline \multicolumn{3}{|l|}{ SUBJECTS TAUGHT } \\
\hline English & 37 & $13.1 \%$ \\
\hline Filipino & 59 & $20.8 \%$ \\
\hline Mathematics & 34 & $12 \%$ \\
\hline Science & 36 & $12.7 \%$ \\
\hline A.P. & 44 & $15.5 \%$ \\
\hline EsP & 26 & $9.2 \%$ \\
\hline T.L.E & 25 & $8.8 \%$ \\
\hline МАРЕН & 18 & $6.4 \%$ \\
\hline Others & 4 & $1.4 \%$ \\
\hline
\end{tabular}




\begin{tabular}{lll}
\hline MONTHLY INCOME & & \\
\hline Php 15,000 - 20, 999 & 102 & $36 \%$ \\
\hline Php 21,000 - 25, 999 & 143 & $50.5 \%$ \\
\hline Php 26,000 - 30, 999 & 24 & $8.5 \%$ \\
\hline Php 31,000 - 35, 999 & 6 & $2.1 \%$ \\
\hline Php 36,000 - 40, 999 & 8 & $2.8 \%$ \\
\hline
\end{tabular}

Note: $\mathrm{n}=\mathbf{2 8 3} \mathrm{f}=$ frequency $\%=$ percentage

Table 4 presents the teacher-respondents' approaches to happiness in terms of pleasant life. The statement, "I am happy when my work priorities in a day are achieved", got the highest weighted mean of 4.58. This means that the teacher-respondents use their strengths and virtues (Seligman, M., E.P., 2002) to accomplish the tasks given to them. It give happiness to the respondents when they achieved their goal in a day likewise teachers are stimulated to work on tasks that gives them the idea of contentment then it results to pleasant life [4].

Table 4

Weighted Mean Distribution of Teacher-Respondents' Approaches to Happiness in Terms of Pleasant Life

\begin{tabular}{llll}
\hline Pleasant life & $\begin{array}{l}\text { Weighted } \\
\text { Mean }\end{array}$ & \multicolumn{2}{l}{$\begin{array}{l}\text { Verbal } \\
\text { Interpretation }\end{array}$} \\
\hline $\begin{array}{l}\text { Life is too short to } \\
\text { postpone the pleasures }\end{array}$ & & Mestly & Like \\
\end{tabular}
it can provide.

\begin{tabular}{llll}
\hline $\begin{array}{l}\text { I go out of my way to } \\
\text { feel happy. }\end{array}$ & $\begin{array}{l}\text { Mostly } \\
\text { Me }\end{array}$ & Like \\
\hline $\begin{array}{l}\text { In choosing what to } \\
\text { do, I always take into }\end{array}$ & & Mostly & Like \\
\end{tabular}
account whether it will be pleasurable.

\begin{tabular}{|c|c|c|}
\hline $\begin{array}{l}\text { I agree with the } \\
\text { statement: "Life is } \\
\text { short - eat desserts } \\
\text { first." Or "Enjoy life } \\
\text { to the fullest." }\end{array}$ & 4.11 & $\begin{array}{l}\text { Mostly Like } \\
\text { Me }\end{array}$ \\
\hline $\begin{array}{l}\text { I love to do things that } \\
\text { excite my senses. }\end{array}$ & 4.26 & $\begin{array}{l}\text { Mostly } \\
\text { Me }\end{array}$ \\
\hline $\begin{array}{l}\text { For me, good life is } \\
\text { pleasurable life. }\end{array}$ & 4.12 & $\begin{array}{l}\text { Mostly } \\
\text { Me }\end{array}$ \\
\hline $\begin{array}{l}\text { I am happy when my } \\
\text { work priorities in a } \\
\text { day are achieved. }\end{array}$ & 4.58 & $\begin{array}{l}\text { Very Much } \\
\text { Like Me }\end{array}$ \\
\hline Weighted & 4.21 & $\begin{array}{l}\text { Mostly } \\
\text { Me }\end{array}$ \\
\hline
\end{tabular}

Table 5 presents the teacher-respondents' approaches to happiness in terms of good life. The statement, "I experience success if the task assigned to me is successfully completed", got the highest weighted mean of 4.55. The result asserts that the teacher-respondents feel fulfillment every time they completed the assigned task. Likewise, Buragohain\&Hazarika (2015) explained that pleasant life includes the engagement in work. It clearly manifests the dedication of the respondents to their job. It brings contentment to their life [7].

Table 5

Weighted Mean Distribution of Teacher-Respondents' Approaches to Happiness in Terms of Good Life

\begin{tabular}{|c|c|c|}
\hline Good life & $\begin{array}{l}\text { Weighed } \\
\text { Mean }\end{array}$ & $\begin{array}{l}\text { Verbal } \\
\text { Interpretation }\end{array}$ \\
\hline $\begin{array}{l}\text { Regardless of what I } \\
\text { am doing, time passes } \\
\text { very quickly. }\end{array}$ & 4.23 & $\begin{array}{l}\text { Mostly } \\
\text { Me }\end{array}$ \\
\hline $\begin{array}{l}\text { I seek out situations } \\
\text { that challenge my skills } \\
\text { and abilities. }\end{array}$ & 4.28 & $\begin{array}{l}\text { Mostly } \\
\text { Me }\end{array}$ \\
\hline $\begin{array}{l}\text { Whether at work or } \\
\text { play, I am usually "in a } \\
\text { zone" and not } \\
\text { conscious of myself. }\end{array}$ & 3.87 & $\begin{array}{l}\text { Mostly } \\
\text { Me }\end{array}$ \\
\hline $\begin{array}{l}\text { I am always very } \\
\text { absorbed in what I do. }\end{array}$ & 4.18 & $\begin{array}{l}\text { Mostly } \\
\text { Me }\end{array}$ \\
\hline $\begin{array}{l}\text { In choosing what to do, } \\
\text { I always take into } \\
\text { account whether I can } \\
\text { lose myself in it. }\end{array}$ & 4.04 & $\begin{array}{l}\text { Mostly } \\
\text { Me }\end{array}$ \\
\hline $\begin{array}{l}\text { I am rarely distracted } \\
\text { by what is going on } \\
\text { around me. }\end{array}$ & 3.94 & $\begin{array}{l}\text { Mostly } \\
\text { Me }\end{array}$ \\
\hline $\begin{array}{l}\text { I experience success if } \\
\text { the task assigned to me } \\
\text { is successfully } \\
\text { completed. }\end{array}$ & 4.55 & $\begin{array}{l}\text { Very Much } \\
\text { Like Me }\end{array}$ \\
\hline $\begin{array}{l}\text { Overall Weighted } \\
\text { Mean }\end{array}$ & 4.16 & $\begin{array}{l}\text { Mostly } \\
\text { Me }\end{array}$ \\
\hline
\end{tabular}

Table 6 shows teacher-respondents approaches to happiness in terms of meaningful life. The statement "My life has a lasting meaning." got the highest weighted mean of 4.49. This manifests that majority of teacher-respondents believe their lives create lasting impact which affects their well-being in general. 
The Relationships of Happiness and Job Satisfaction to Job Performance of Public Secondary School Teachers in Selected Schools in the Division of Cavite

Table 6

Weighted Mean Distribution of Teacher-Respondents' Approaches to Happiness in Terms of Meaningful Life

\begin{tabular}{|c|c|c|c|}
\hline Meaningful life & $\begin{array}{l}\text { Weighed } \\
\text { Mean }\end{array}$ & $\begin{array}{l}\text { Verbal } \\
\text { Interp }\end{array}$ & ation \\
\hline $\begin{array}{l}\text { My life serves a higher } \\
\text { purpose. }\end{array}$ & 4.44 & $\begin{array}{l}\text { Mostly } \\
\text { Me }\end{array}$ & Like \\
\hline $\begin{array}{l}\text { In choosing what to do, I } \\
\text { always take into account } \\
\text { whether it will benefit } \\
\text { other people. }\end{array}$ & 4.28 & $\begin{array}{l}\text { Mostly } \\
\text { Me }\end{array}$ & Like \\
\hline $\begin{array}{l}\text { I have a responsibility to } \\
\text { make the world a better } \\
\text { place. }\end{array}$ & 4.41 & $\begin{array}{l}\text { Mostly } \\
\text { Me }\end{array}$ & \\
\hline $\begin{array}{l}\text { My life has a lasting } \\
\text { meaning. }\end{array}$ & 4.49 & $\begin{array}{l}\text { Mostly } \\
\text { Me }\end{array}$ & Like \\
\hline $\begin{array}{l}\text { What I do, matters to } \\
\text { society. }\end{array}$ & 4.26 & $\begin{array}{l}\text { Mostly } \\
\text { Me }\end{array}$ & Like \\
\hline $\begin{array}{l}\text { I have spent a lot of time } \\
\text { thinking about what life } \\
\text { means and how I fit into } \\
\text { its big picture. }\end{array}$ & 4.28 & $\begin{array}{l}\text { Mostly } \\
\mathrm{Me}\end{array}$ & \\
\hline
\end{tabular}

\begin{tabular}{|l|l|l|ll|}
\hline $\begin{array}{l}\text { I feel happy if my } \\
\text { recommendations are }\end{array}$ & 4.34 & $\begin{array}{l}\text { Mostly } \\
\text { Me }\end{array}$ & Like \\
implemented in my \\
school.
\end{tabular}

Table 7 reveals the weighted mean distribution of teacher-respondents' job satisfaction in terms of motivators or intrinsic factors that lead to job satisfaction. These are the statements that got the highest weighted mean in every motivator or intrinsic factor; achievement highest weighted mean is 4.29 in the statement, "I feel have contributed towards my company in a positive manner." ,advancement highest weighted mean is4.24 in the statement, "My job allows me to learn new skills for career advancement.", work itself highest weighted mean is 4.26 in the statement, "My job is challenging and exciting.", recognition highest weighted mean is 4.33 in the statement "I feel appreciated when I achieve or complete a task." and growth highest weighted mean is 4.31 in the statements "My job allows me to grow and develop as a person and my job allows me to improve my skills and performance."

Table 7

Weighted Mean Distribution of Teacher-Respondents' Job Satisfaction in Terms of Motivators/Intrinsic Factors that Lead to Job Satisfaction

\begin{tabular}{|c|c|c|}
\hline $\begin{array}{l}\text { Motivators/Intrinsic Factors that Lead to Job } \\
\text { Satisfaction }\end{array}$ & Weighted Mean & Verbal Interpretation \\
\hline \multicolumn{3}{|l|}{ OVERALL ACHIEVEMENT } \\
\hline $\begin{array}{l}\text { I am proud to work in this organization because it } \\
\text { recognizes my achievements. }\end{array}$ & 4.20 & Agree \\
\hline $\begin{array}{l}\text { I feel satisfied with my job because it gives me } \\
\text { feeling of accomplishment. }\end{array}$ & 4.28 & Agree \\
\hline $\begin{array}{l}\text { I feel I have contributed towards my company in a } \\
\text { positive manner. }\end{array}$ & 4.29 & Agree \\
\hline Weighted Mean & 4.26 & Agree \\
\hline \multicolumn{3}{|l|}{ OVERALL ADVANCEMENT } \\
\hline $\begin{array}{l}\text { I will choose career advancement rather than } \\
\text { monetary incentives. }\end{array}$ & 4.23 & Agree \\
\hline $\begin{array}{l}\text { My job allows me to learn new skills for career } \\
\text { advancement. }\end{array}$ & 4.24 & Agree \\
\hline $\begin{array}{l}\text { I am given opportunities to engage in activities that } \\
\text { will lead to my promotion on the job. }\end{array}$ & 4.14 & Agree \\
\hline Weighted Mean & 4.20 & Agree \\
\hline \multicolumn{3}{|l|}{ OVERALL WORK ITSELF } \\
\hline $\begin{array}{l}\text { My work is exciting and I have a lot of variety in } \\
\text { tasks that I do. }\end{array}$ & 4.12 & Agree \\
\hline I am empowered enough to do my job. & 4.17 & Agree \\
\hline My job is challenging and exciting. & 4.26 & Agree \\
\hline Weighted Mean & 4.18 & Agree \\
\hline \multicolumn{3}{|l|}{ OVERALL RECOGNITION } \\
\hline $\begin{array}{l}\text { I feel appreciated when I achieve or complete a } \\
\text { task. }\end{array}$ & 4.33 & Agree \\
\hline $\begin{array}{l}\text { My department head and/or principal always } \\
\text { thanks me for a job well done. }\end{array}$ & 4.07 & Agree \\
\hline $\begin{array}{l}\text { I receive adequate recognition for helping out on } \\
\text { tasks in the organization. }\end{array}$ & 4.01 & Agree \\
\hline
\end{tabular}




\begin{tabular}{|c|c|c|}
\hline $\begin{array}{l}\text { I receive adequate recognition for doing a job well } \\
\text { assigned to me. }\end{array}$ & 4.07 & Agree \\
\hline Weighted Mean & 4.12 & Agree \\
\hline \multicolumn{3}{|l|}{ OVERALL GROWTH } \\
\hline $\begin{array}{l}\text { I am proud to work in my company because I feel I } \\
\text { have grown as a person. }\end{array}$ & 4.18 & Agree \\
\hline My job allows me to grow and develop as a person. & 4.31 & Agree \\
\hline $\begin{array}{l}\text { My job allows me to improve my skills and } \\
\text { performance. }\end{array}$ & 4.31 & Agree \\
\hline $\begin{array}{l}\text { I am learning and capacitated to improve my } \\
\text { performance at work. }\end{array}$ & 4.24 & Agree \\
\hline Weighted Mean & 4.26 & Agree \\
\hline Overall Weighted Mean & 4.20 & Agree \\
\hline
\end{tabular}

Table 8 presents the weighted mean distribution of teacher-respondents' job satisfaction in terms of hygiene factors or extrinsic factors that prevent job dissatisfaction. These are the statements that got the highest weighted mean each hygiene factors or extrinsic factor: company policy highest weighted mean is 4.25 in the statement, "I completely understand and subscribe to the mission and vision of the Department of Education.", relationship with peers highest weighted mean is 4.42 with the statement, "My co-teachers are important to me.", overall work security highest weighted mean is 4.28 with the statement," I feel secured in my job.",

\section{Table 8} with the statement, "My department head and/or principal is/are strong and trustworthy leaders.", overall salary highest weighted mean is 4.00 with the statement," I am encouraged to work harder because of my salary." and working conditions highest weighted mean is 4.11 with the statement," I am proud to work for my company because of the pleasant working conditions." On the contrary, the statement, "I am encouraged to work harder because of my salary." under salary is the lowest weighted mean with 4.00. Alemi (2014) also found out that teachers are dissatisfied to their salary according to his research [22].

ents' Job Satisfaction in Terms of Hygiene Factors/Extrinsic

Weighted Mean Distribution of Teacher-Respondents' Job Satisfaction in
Factors that Prevent Job Dissatisfaction

\begin{tabular}{l}
$\begin{array}{l}\text { Hygiene Factors/Extrinsic Factors that } \\
\text { Prevent Job Dissatisfaction }\end{array}$ \\
$\begin{array}{l}\text { OVERALL COMPANY POLICY } \\
\begin{array}{l}\text { The attitude of the administration is very } \\
\text { supportive in my school. }\end{array}\end{array}$ \\
$\begin{array}{l}\text { I am proud to work for this organization } \\
\text { because the school policy is favorable to the } \\
\text { teachers. }\end{array}$ \\
$\begin{array}{l}\text { I completely understand and subscribe to } 4.01 \\
\text { Agree }\end{array}$ \\
\hline
\end{tabular}
the mission and vision of the Department of Education.

\begin{tabular}{lll}
\hline Weighted Mean & $\mathbf{4 . 1 3}$ & Agree \\
\hline OVERALL RELATIONSHIP WITH PEERS & & \\
\hline It is easy to get along with my co-teachers. & 4.28 & Agree \\
\hline My co-teachers are helpful and friendly. & 4.37 & Agree \\
\hline My co-teachers are important to me. & 4.42 & Agree \\
\hline Weighted Mean & $\mathbf{4 . 3 6}$ & Agree \\
\hline OVERALL WORK SECURITY & \\
\hline I believe it is safe working at my workplace. & 4.21 & Agree \\
\hline I feel secured in my job. & 4.28 & Agree \\
\hline $\begin{array}{l}\text { My workplace is located in an area where I } \\
\text { am comfortable. }\end{array}$ & 4.16 & Agree \\
\hline Weighted Mean & $\mathbf{4 . 2 2}$ & Agree \\
\hline $\begin{array}{l}\text { OVERALL RELATIONSHIP WITH SUPERVISOR } \\
\text { feel my performance has improved }\end{array}$ & 4.10 & Agree \\
\hline $\begin{array}{l}\text { because of the support from my department } \\
\text { head and/or principal. }\end{array}$ & \\
\hline
\end{tabular}


The Relationships of Happiness and Job Satisfaction to Job Performance of Public Secondary School Teachers in Selected Schools in the Division of Cavite

\begin{tabular}{lll}
\hline $\begin{array}{l}\text { I feel satisfied at work because of my } \\
\text { relationship with my department head and/or } \\
\text { principal. }\end{array}$ & 4.13 & Agree \\
$\begin{array}{l}\text { My department head and/or principal is/are } \\
\text { strong and trustworthy leaders. }\end{array}$ & 4.21 & Agree \\
\hline Weighted Mean & $\mathbf{4 . 1 5}$ & Agree \\
\hline OVERALL SALARY & & Agree \\
\hline $\begin{array}{l}\text { I am encouraged to work harder because of } \\
\text { my salary. }\end{array}$ & 4.00 & Agree \\
\hline I believe that my salary is fair. & 3.93 & Agree \\
\hline Weighted Mean & 3.97 & Agree \\
\hline $\begin{array}{l}\text { OVERALL WORKING CONDITIONS } \\
\text { I feel satisfied because of the comfort I am } \\
\text { provided at work. }\end{array}$ & 4.06 & Agree \\
\hline $\begin{array}{l}\text { I am proud to work for my company } \\
\text { because of the pleasant working conditions. }\end{array}$ & 4.11 & Agree \\
\hline Weighted Mean & 4.09 & Agree \\
\hline Overall Weighted Mean & $\mathbf{4 . 1 7}$ & \\
\hline
\end{tabular}

Table 9 presents the job performance of teacher-respondents in terms of their Individual Performance Commitment and Review Form (IPCRF) Ratings. Two hundred thirty-one (231) or eighty-one point six percent $(81.6 \%)$ of the teacher-respondents got "Very Satisfactory" rating, while forty-eight (48) or seventeen percent (17\%) got "Outstanding" rating. This is followed by four (4) or one point four percent (1.4\%) who got "Satisfactory" and no one got "Unsatisfactory" and "Poor" performance ratings. According to based performance management system (DepEd Order No. 2, S. 2015) allows a discussion between the superior and employee with regards to job expectations, key results areas, objectives and other related topic for the improvement of teacher and department itself. This will help the teacher and the head teacher or Master teacher to build a good relationship through communication for education purposes.

Table 9

Frequency, Percentage, and Weighted Mean

Distribution of Teacher-Respondents' Job Performance based on IPCRF Ratings

\begin{tabular}{|c|c|c|c|c|c|}
\hline $\begin{array}{l}\text { IPRC } \\
\text { F } \\
\text { Ratin } \\
\text { gs }\end{array}$ & $\begin{array}{l}\text { Ra } \\
\text { nge }\end{array}$ & $\begin{array}{l}\text { Fre } \\
\text { que } \\
\text { ncy }\end{array}$ & $\begin{array}{l}\text { Percen } \\
\text { tage } \\
(\%)\end{array}$ & $\begin{array}{l}\text { Weig } \\
\text { hted } \\
\text { Mea } \\
\text { n }\end{array}$ & $\begin{array}{l}\text { Verbal } \\
\text { Interpre } \\
\text { tation }\end{array}$ \\
\hline $\begin{array}{l}\text { Outst } \\
\text { andin } \\
\text { g }\end{array}$ & $\begin{array}{l}4.5 \\
0-5 . \\
00\end{array}$ & 48 & $17.0 \%$ & \multirow{5}{*}{4.16} & \multirow{5}{*}{$\begin{array}{l}\text { Very } \\
\text { Satisfact } \\
\text { ory }\end{array}$} \\
\hline $\begin{array}{l}\text { Very } \\
\text { Satisf } \\
\text { actor } \\
\text { y }\end{array}$ & $\begin{array}{l}3.5 \\
0-4 . \\
49\end{array}$ & 231 & $81.6 \%$ & & \\
\hline $\begin{array}{l}\text { Satisf } \\
\text { actor } \\
\text { y }\end{array}$ & $\begin{array}{l}2.5 \\
0-3 . \\
49\end{array}$ & 4 & $1.4 \%$ & & \\
\hline $\begin{array}{l}\text { Unsat } \\
\text { isfact } \\
\text { ory }\end{array}$ & $\begin{array}{l}1.5 \\
0-2 . \\
49\end{array}$ & 0 & $0 \%$ & & \\
\hline Poor & $\begin{array}{l}\text { Bel } \\
\text { ow- } \\
1.4 \\
9\end{array}$ & 0 & $0 \%$ & & \\
\hline
\end{tabular}

Table 10 shows the relationship between the teacher-respondents Approaches to Happiness and Job Performance when they are group according to job performance using the Pearson Product Moment Correlation Coefficient test. The Pearson $r$ Correlation of -0.002 and 0.175 indicates that there is a Very Weak Negative Relationship between happiness of teacher-respondents in terms of pleasant life, good life and job performance. Likewise, Overall Happiness of Teacher-respondents and Job Performance because of the result of the Pearson $r$ Correlation which is 0.131 
Table 10

Pearson's Correlation between the Approaches to Happiness and Job Performance

\begin{tabular}{|c|c|c|c|c|c|}
\hline $\begin{array}{l}\text { Appro } \\
\text { aches } \\
\text { to } \\
\text { Happi } \\
\text { ness } \\
\text { vs Job } \\
\text { Perfor } \\
\text { mance }\end{array}$ & $\begin{array}{l}\text { Pea } \\
\text { rso } \\
\text { n r } \\
\text { Cor } \\
\text { rela } \\
\text { tion }\end{array}$ & $\begin{array}{l}\text { Verbal } \\
\text { Interpre } \\
\text { tation }\end{array}$ & $\begin{array}{l}\text { p-va } \\
\text { lue }\end{array}$ & $\begin{array}{l}\text { Decisi } \\
\text { on }\end{array}$ & Remarks \\
\hline $\begin{array}{l}\text { Pleasa } \\
\text { nt Life }\end{array}$ & $\begin{array}{l}-0.0 \\
02\end{array}$ & $\begin{array}{l}\text { Very } \\
\text { Weak } \\
\text { Negative } \\
\text { Relations } \\
\text { hip }\end{array}$ & $\begin{array}{l}0.96 \\
80\end{array}$ & $\begin{array}{l}\text { Failed } \\
\text { to } \\
\text { Reject } \\
\mathrm{H}_{0}\end{array}$ & $\begin{array}{l}\text { No } \\
\text { significa } \\
\text { nt } \\
\text { relations } \\
\text { hip }\end{array}$ \\
\hline $\begin{array}{l}\text { Good } \\
\text { Life }\end{array}$ & $\begin{array}{l}0.17 \\
5\end{array}$ & $\begin{array}{l}\text { Very } \\
\text { Weak } \\
\text { Positive } \\
\text { Relations } \\
\text { hip }\end{array}$ & $\begin{array}{l}0.00 \\
30\end{array}$ & $\begin{array}{l}\text { Reject } \\
\mathrm{H}_{0}\end{array}$ & $\begin{array}{l}\text { Significa } \\
\text { nt } \\
\text { relations } \\
\text { hip }\end{array}$ \\
\hline
\end{tabular}

\begin{tabular}{|l|l|l|l|l|l|}
\hline $\begin{array}{l}\text { Meani } \\
\text { ngful } \\
\text { Life }\end{array}$ & 0.20 & $\begin{array}{l}\text { Weak } \\
\text { Positive } \\
\text { Relations } \\
\text { hip }\end{array}$ & 04 & $\begin{array}{l}\text { Reject } \\
\mathrm{H}_{0}\end{array}$ & $\begin{array}{l}\text { Significa } \\
\text { nt } \\
\text { relations } \\
\text { hip }\end{array}$ \\
\hline $\begin{array}{l}\text { Overa } \\
\text { ll }\end{array}$ & $\mathbf{0 . 1 3}$ & $\begin{array}{l}\text { Very } \\
\text { Weak }\end{array}$ & $\begin{array}{l}\mathbf{0 . 0 2} \\
\text { Positive } \\
\text { Relation } \\
\text { ship }\end{array}$ & $\begin{array}{l}\text { Reject } \\
\text { Significa }\end{array}$ & $\begin{array}{l}\text { Ho } \\
\text { nt } \\
\text { relations } \\
\text { hip }\end{array}$ \\
\hline
\end{tabular}

Table 11 elaborates the relationship between the job satisfaction of the teacher-respondents when they are group according to the job performance using the Pearson Product Moment Correlation Coefficient Test. The Pearson $r$ Correlation are all Very Weak Positive Relationship between Job Satisfaction in terms of Motivators-Recognition and Hygiene Factors Company Policy and Job Performance. Achievement and Advancement got the highest score with both 0.135 .

Table 11

Pearson's Correlation between the Teacher-Respondents' Job Satisfaction and Job Performance

\begin{tabular}{|c|c|c|c|c|c|}
\hline $\begin{array}{lr}\text { Job } & \text { Satisfaction } \\
\text { vs } & \text { Job } \\
\text { Performance } & \end{array}$ & $\begin{array}{l}\text { Pearson } \\
\mathbf{r} \\
\text { Correla } \\
\text { tion }\end{array}$ & Verbal Interpretation & p-value & Decision & Remarks \\
\hline
\end{tabular}

Motivators/Intrinsic Factors that Lead to Job Satisfaction

\begin{tabular}{|l|l|l|l|l|l|}
\hline Achievement & 0.135 & Very weak positive relationship & 0.023 & Reject $\mathrm{H}_{0}$ & Significant Relationship \\
\hline Advancement & 0.135 & Very weak positive relationship & 0.023 & Reject $\mathrm{H}_{0}$ & Significant Relationship \\
\hline Work Itself & 0.107 & Very weak positive relationship & 0.072 & Accept $\mathrm{H}_{0}$ & No Significant Relationship \\
\hline Recognition & 0.102 & Very weak positive relationship & 0.085 & Accept $\mathrm{H}_{0}$ & No Significant Relationship \\
\hline Growth & 0.115 & Very weak positive relationship & 0.053 & Accept $\mathrm{H}_{0}$ & No Significant Relationship
\end{tabular}

Hygiene Factors/Extrinsic Factors that Prevent Job Dissatisfaction

\begin{tabular}{|c|c|c|c|c|c|}
\hline Company Policy & 0.088 & Very weak positive relationship & 0.138 & Accept $\mathrm{H}_{0}$ & No Significant Relationship \\
\hline $\begin{array}{l}\text { Relationship with } \\
\text { Peers }\end{array}$ & 0.009 & Very weak positive relationship & 0.880 & Accept $\mathrm{H}_{0}$ & No Significant Relationship \\
\hline Work Security & 0.104 & Very weak positive relationship & 0.080 & Accept $\mathrm{H}_{0}$ & No Significant Relationship \\
\hline $\begin{array}{l}\text { Relationship with } \\
\text { Supervisor }\end{array}$ & 0.171 & Very weak positive relationship & 0.004 & Reject $\mathrm{H}_{0}$ & Significant Relationship \\
\hline Salary & 0.118 & Very weak positive relationship & 0.048 & Reject $\mathrm{H}_{0}$ & Significant Relationship \\
\hline $\begin{array}{l}\text { Working } \\
\text { Conditions }\end{array}$ & 0.124 & Very weak positive relationship & 0.037 & Reject $\mathrm{H}_{0}$ & Significant Relationship \\
\hline Overall & 0.131 & $\begin{array}{l}\text { Very weak positive } \\
\text { relationship }\end{array}$ & 0.028 & Reject $\mathbf{H}_{0}$ & Significant Relationship \\
\hline
\end{tabular}

Table 12 presents the MLR analysis that test statistical significance between all studied parameters. The factor which have significant aspect in the teacher-respondents' job performance are pleasant life, good life, and meaningful life which are categorized under approaches to happiness.
Pleasant life has the highest score with 0.000 . The results confirm that the relationship between approaches to happiness and job performance is statistically significant. 
The Relationships of Happiness and Job Satisfaction to Job Performance of Public Secondary School Teachers in Selected Schools in the Division of Cavite

Table 12

Multiple Linear Regression Analysis between the Teacher-Respondents' Approaches to Happiness and Job Satisfaction to Job Performance

\begin{tabular}{|c|c|c|c|c|}
\hline Factors & $\mathbf{t}$ & P-value & Decision & Remarks \\
\hline \multicolumn{5}{|c|}{ Approaches to Happiness } \\
\hline Pleasant Life & -3.731 & 0.000 & Reject $\mathrm{H}_{0}$ & Significant \\
\hline Good Life & 2.491 & 0.013 & Reject $\mathrm{H}_{0}$ & Significant \\
\hline Meaningful Life & 2.024 & 0.044 & Reject $\mathrm{H}_{0}$ & Significant \\
\hline \multicolumn{5}{|c|}{ Job Satisfaction Index (Motivators/Intrinsic Factors) } \\
\hline Work Itself & -0.104 & .917 & Accept $\mathrm{H}_{0}$ & Not Significant \\
\hline Advancement & -0.905 & .366 & Accept $\mathrm{H}_{0}$ & Not Significant \\
\hline Achievement & 1.340 & .182 & Accept $\mathrm{H}_{0}$ & Not Significant \\
\hline Recognition & -0.829 & .408 & Accept $\mathrm{H}_{0}$ & Not Significant \\
\hline Growth & 0.191 & .849 & Accept $\mathrm{H}_{0}$ & Not Significant \\
\hline \multicolumn{5}{|c|}{ Job Satisfaction Index (Hygiene/Extrinsic Factors) } \\
\hline Company Policy & -0.455 & .650 & Accept $\mathrm{H}_{0}$ & Not Significant \\
\hline Relationship with Peers & -1.394 & .165 & Accept $\mathrm{H}_{0}$ & Not Significant \\
\hline Work Security & -0.649 & .517 & Accept $\mathrm{H}_{0}$ & Not Significant \\
\hline Relationship With Supervisor & 1.940 & .053 & Accept $\mathrm{H}_{0}$ & Not Significant \\
\hline Salary & 0.238 & .812 & Accept $\mathrm{H}_{0}$ & Not Significant \\
\hline Work Conditions & 0.457 & .648 & Accept $\mathrm{H}_{0}$ & Not Significant \\
\hline
\end{tabular}

\section{CONCLUSION AND RECOMMENDATION}

The public secondary school teachers in the selected schools in the Division of Cavite are most likely happy, living a "full life" that satisfies all three criteria of happiness - pleasant life, good life, and meaningful life. Majority of teacher-respondents stated that there are factors in their job which are consistently related to and drive job satisfaction, such as appreciation of their achievements and support for their career advancement and professional growth. Teacher-respondents also cited certain aspects in their job which are associated with the deterrence of job dissatisfaction like relationships with peers and supervisor as well as work security. In terms of overall job performance, teacher-respondents have exceeded job expectations in terms of quality of work, efficiency, and timeliness. Furthermore, teacher-respondents were considered better performers wherein all goals and performance targets were achieved above the established standards.

The findings of this study indicated that the extent of correlation between the approaches to happiness and job performance and between the job satisfaction and job performance are both significant. When these variables are linked with job performance, the outcome revealed that higher degrees of happiness and job satisfaction lead to very satisfactory job performance.

To further improve the level of workplace happiness and job satisfaction of teachers, the researchers highly recommend that the education sector administration facilitate the provision of proper recognition to teacher whenever a task assigned or a key milestone is successfully done. It can be in a form of a certification, cash gift, scholarship grant, participation in an international or national training or seminar, promotion points, or assignment to bigger responsibilities. It is also particularly important for school administrators to encourage teachers to pursue career advancement and professional growth, not only to ensure the best learning outcomes for their students, but also to be more effective and satisfied in other aspects of their work. To advance the positive causality of approaches to happiness and job satisfaction the researchers also recommend the conduct of open dialogue with institutional leaders and school administrators to build and strengthen rapport (Joson, 2016) [34]. This engagement aims to talk through existing problems and consider alternatives in resolving certain issues as well as to come up with programs that can better aid the students, teachers, and community as a whole. Keeping the teachers up-to-date with the latest trends in the Department of Education would be a great help. Ensure that the policy and/or changes in policy are well explained so that no teacher is left uninformed or confused.

There may be other factors that may affect workplace happiness and job satisfaction level which the study did not explicitly explore. Further studies must be done on such aspects in relation to type of work, school culture, organizational climate, and leadership styles of principals, among others. 


\section{REFERENCES}

1. Nicholls, A. (2017, October 25). Jobstreet: Filipinos less happy at work. Retrieved from http://cnnphilippines.com/news/2017/10/25/Filipinos-wo rk-satisfaction-Jobstreet.html

2. Amabile, T., \& Kramer, S. (2011, September 3). Do happier people work harder. Retrieved from The New York Times website: http://www.nytimes.com/2011/09/04/opinion/ sunday/do-happier-people-work-harder.html

3. Harris, K., Hinds, L., Manansingh, S., Rubino, M., \&Morote, E. (2016). What type of Leadership in Higher Education Promotes Job Satisfaction and Increases Retention? Journal for Leadership and Instruction. Retrieved from https://files.eric.ed.gov/fulltext/ EJ1097552.pdf.

4. Seligman, M. E. P. Authentic Happiness: Using the New Positive Psychology to realize your potential for lasting fulfillment. Nicholas Brealey: London, 2002.

5. Proto, E. "Are Happy Workers More Productive?” IZA World of Labor, December 2016, pp. 1-8. doi:10.15185/izawol.315.

6. Scorsolini-Comin, F., Fontaine, A.M.G.V., Koller, S.H., \& dos Santos, M.A. "From Authentic Happiness to Well-Being: the Flourishing of Positive Psychology." Psicologia: ReflexÃ£o e CrÃ̃Tica, vol. 26, no. 4, 2013, pp. 663-670., doi:10.1590/s0102-79722013000400006.

7. Buragohain, P. \&Hazarika, M. (2015, May 31). Happiness Level of Secondary School Teachers in Relation to their Job Satisfaction. SSRG International Journal of Humanities and Social Science (SSRG-IJHSS), 2(3), 19-37.

8. Peterson, C., Park, N., \& Seligman, M. E. P. (2005). Orientations to Happiness and Life Satisfaction: The Full Life Versus The Empty Life. Journal of Happiness Studies, 6:25-41 doi:10.1007/s10902-004-1278-z.

9. Brdar, I. (2016, January 8). Approaches to Happiness, Life Goals, and Well-Being. ResearchGate, 1-15.

10. Anić, P. \&Tončić, M. Orientations to Happiness, Subjective Well-being and Life Goals. Rijeka, Department of Psychology, Faculty of Humanities and Social Sciences, University of Rijeka, 2009, pp. 135-53.

11. Asiyabi, M., \&Mirabi, V. (2012). Investigation of Contributing Factors in Employees' Desertion in Power Engineering Consultants (Moshanir) Company. Interdisciplinary Journal of Contemporary Research inBusiness, 4(6), 1183-1199.

12. Fisher, C. D. (2010, December 31). Happiness at Work. International Journal of Management Reviews, 12(1), doi:10.1111/j.1468-2370.2009.00270.

13. Wesarat, P., Sharif, M.Y., \& Abdul Majid, A.H. (2014). A Conceptual Framework of Happiness at the Workplace, Vol. 11, 78-88. http://dx.doi.org/10.5539/ass.v11n2p78

14. Bakker, A. B., \&Oerlemans, W. (2011). Subjective Well-being in Organizations. In K. S. Cameron \& G. M. Spreitzer (Eds.), The Oxford Handbook of Positive Organizational Scholarship (pp. 178-189). New York: Oxford University Press.

15. Hoppock, R. (1935), Job Satisfaction,New York: Harpe.

16. Locke, Edwin. (1969). What is Job Satisfaction?. Organizational Behavior and Human Performance. 4. 309-336. 10.1016/0030-5073(69)90013-0.

17. Statt, D. (2004). The Routledge Dictionary of Business Management, Third Edition, Routledge Publishing, Detroit, p. 78.

18. Armstrong, M. (2006). A Handbook of Human Resource Management Practice (10th Ed.). London: Kogan Page.

19. Robbins, S.P. \& Judge, T.A. (2007). An Introduction to Organizational Behavior.12 $2^{\text {th }}$ Edition. Philippines:
Pearson Education South Asia Pte. Ltd.

20. Cook, A.L. (2008). Job Satisfaction and Job Performance: Is the relationship spurious? M.A. Thesis, A\&M University, Texas.

21. Alegre, L.A., Gomez, M.A., Lopez, Z.R., \&Mapa, C.B. (1999). Elements of Office Systems and Administrative Principles (Philippine Setting). Philippines: Booklore Publishing Corp

22. Alemi, B. (2014). Job Satisfaction Among Afghan Teacher Educators (Master's thesis). 28 February 2014.

23. Thakur, N. (2014). A Comparative Study on Job Satisfaction of Teacher Educators in Relation to Private Teachers' Training Institutions of University of GourBanga and University of Kalyani. International Journal of Education and Psychological Research,(IJEPR), 3(4), 1-5.

24. Abdullah, M., Uli, J., \&Salahudin, S. (2007, August 18). Job Satisfaction of Secondary School Teachers in Tawau, Sabah. In PerpustakaanSultanahBahiyah. Retrieved from http://repo.uum.edu.my/1737.

25. De Kok, C. (2013). Happiness At Work: Are Job Satisfaction, Job Self-Efficacy And TraitEmotional Intelligence Related? (Master's Thesis). January 2013.

26. Subhashini. D (2017). A study on the impact of Job Satisfaction on Job Performance ofEmployees working in Automobile Industry, Punjab, India, Vol. 9,117-130.http://dx.doi.org/10.5296/jmr.v9i1.10420.

27. Üredi, L. (2017, November 12). Investigating the Relationship between Job Satisfaction Levels of the Teachers in Educational Institutions and Their Attitudes towards Teaching Profession. Journal of Education and Practice, 8, 175-182.

28. Usop, A., Askandar, K., Langguyuan-Kadtong, M., \&Onotan-Usop, D. (2013, March 31).Work Performance and Job Satisfaction among Teachers. International Journal ofHumanities and Social Science, 3(5), 245-252.

29. Riley, Tammie. 6 Reasons Why Having a Job/Career is So Important. Retrieved from https://www.linkedin.com/pulse/6-reasons-why-having-j obcareer-so-important-tammie-riley.

30. Ali, A. (1996). Fundamental of research in education. Awka: Meks. Unique Publisher's Ltd.

31. Hinkle, Wiersma\&Jurs, . (2003). Applied Statistics for the Behavioral Sciences (5th Editionthed.).

32. ABDULLAH, SEASONSSAMSURI, et al. MULTIPLE LINEAR REGRESSION (MLR) MODELS FOR LONG TERM PMIO CONCENTRATION FORECASTING DURING DIFFERENT MONSOON SEASONS. 1 ed., vol 12, Journal of Sustainability Science and Management, 2017, pp. 60-68. 